\title{
Testing species boundaries between Atlantic and Pacific lineages of the Patagonian rockfish Sebastes oculatus (Teleostei: Scorpaenidae) through mitochondrial DNA sequences
}

Evaluando límites específicos entre los linajes Atlántico y Pacífico de Sebastes oculatus (Teleostei: Scorpaenidae) a través de secuencias de ADN mitocondrial

\author{
José J. Nuñez ${ }^{1}$, M. Teresa González ${ }^{2}$ and Marcos Pérez-Losada ${ }^{3}$
}

\author{
${ }^{1}$ Instituto de Zoología, Universidad Austral de Chile, Casilla 567, Valdivia, Chile. jjnunezn@gmail.com \\ ${ }^{2}$ Instituto de Investigaciones Oceanológicas, Universidad de Antofagasta, Casilla 170, Antofagasta, Chile \\ ${ }^{3}$ Centro de Investigação em Biodiversidade e Recursos Genéticos, Universidade do Porto, Campus Agrário de Vairão 4485-661 \\ Vairão, Portugal
}

Resumen.- Se investigó la diferenciación genética y límites de especies entre los linajes Atlántico y Pacífico de Sebastes oculatus a través de secuencias de la región D-loop del ADN mitocondrial (541bp). Las secuencias se obtuvieron de 47 individuos de siete localidades de las costas del Pacífico y Atlántico de Sudamérica (S. oculatus) y una localidad de Sudáfrica (S. capensis). Adicionalmente, se obtuvieron dos secuencias de Helicolenus lengerichi que fueron utilizadas como grupo externo. Estos datos fueron combinados con secuencias disponibles en GenBank correspondientes a 21 especies de Sebastes. Las aproximaciones de máxima verosimilitud y análisis Bayesiano mostraron distintividad topológica entre las poblaciones sudamericanas y africanas de Sebastes, apoyando la existencia de dos especies filogenéticas: S. oculatus y S. capensis. Sin embargo, las poblaciones del Pacífico y del Atlántico de S. oculatus no formaron grupos monofiléticos recíprocos. La aplicación del protocolo de Wiens \& Penkrot para evaluar límites entre especies no apoyó la existencia de dos especies en las costas de Sudamérica. El flujo génico entre las poblaciones de S. oculatus podría ser explicado por una extensa dispersión larval favorecida tanto por la corriente de Humboldt y la Corriente de la Deriva del Oeste a lo largo de las costas de Sudamérica.

Palabras clave: Hemisferio sur, cabrilla, mtDNA, especiación

\begin{abstract}
Genetic differentiation and species boundaries between Atlantic and Pacific lineages of the Patagonian rockfish Sebastes oculatus was investigated using mtDNA D-loop partial sequences (541 bp). Sequences were obtained for 47 individuals from seven locations off the Pacific and Atlantic coasts of South America (S. oculatus) and one off the coast of South Africa (S. capensis), and for two specimens of Helicolenus lengerichi (outgroup). These data were then combined with sequences from GenBank corresponding to 21 Sebastes species. Maximum likelihood and Bayesian phylogenetic approaches showed topological distinctiveness between South American and South African Sebastes populations, supporting the existence of two phylogenetic species: S. oculatus and S. capensis. However, Atlantic and Pacific populations of S. oculatus, did not form reciprocal monophyletic assemblages. Application of the Wiens \& Penkrot's protocol to test species boundaries within this species did not support the existence of two different phylogenetic taxa. Gene flow between Atlantic and Pacific populations of S. oculatus could be explained by extensive larval dispersal, favored by both the Humboldt current and the West Wind Drift current along the South American coast.
\end{abstract}

Key words: Southern hemisphere, rockfishes, mtDNA, speciation

\section{INTRODUCTION}

Rockfishes of the genus Sebastes Cuvier, 1829 comprise over 110 species, constituting one of the most diverse genera of marine fishes (Nelson 1994, Kendall 2000). Most of this species diversity is explained by allopatric speciation (Narum et al. 2004), although a few cases, mainly those described at local scale, are explained by reproductive isolation mechanisms such as complex mating behavior (Gingras et al. 1998) and pronounced color polymorphism (Orr \& Blackburn 2004). Sebastes species are mostly distributed across the continental shelf and shoreline waters (less than $500 \mathrm{~m}$ deep) of the northern hemisphere (Chen 1971, Johns \& Avise 1998, Hyde \& Vetter 2007), 
but some rockfish species also occur in the western and eastern Atlantic and eastern Pacific basins of the southern hemisphere (Barsukov 1988, Stransky \& MacLellan 2005). In fact, two closely related species of Sebastes are currently recognized in the southern hemisphere: Sebastes capensis (Gmelin, 1789) distributed from the Tristan da Cunha Island to the southwestern coast of South Africa, and Sebastes oculatus (Valenciennes, 1833) distributed from the Pacific coast of Peru and Chile to the Falkland Islands in the Atlantic (Stransky \& MacLellan 2005).

Despite the recognition of both entities, the specific boundaries and geographic limits of $S$. oculatus remain unclear and controversial. Rocha-Olivares et al. (1999a), using mitochondrial DNA sequence genetic analysis, proposed that the populations from off South Africa waters should be considered $S$. capensis, and those populations from off western and southeastern South America waters should be named S. oculatus. Posteriorly, Rocha-Olivares et al. (1999b) performed a geographically more extensive genetic analysis and recognized three distinctive lineages as possible cryptic species: a $S$. capensis lineage found around Tristan da Cunha and off the coast of southwestern South Africa, a southwestern Atlantic oculatus lineage from the Falkland Islands and Argentina, and a southeastern Pacific oculatus lineage from Chile and Peru. However, due to their limited sampling along the southeastern Pacific coast, Rocha-Olivares et al. (1999b) concluded that these results must be interpreted with caution and would require further comparative studies.

Recent development of theoretical and operational approaches to species delimitation (Wiens \& Penkrot 2002, Sites \& Marshall 2004, Wiens 2007, Bond \& Stockman
2008, Ross et al. 2008) coupled to sequence data analyses, have allowed to test the validity of taxonomic nomenclature against phylogenetic hypotheses. In this sense, due that mitochondrial DNA (mtDNA) coalesce faster than nuclear DNA (Palumbi et al. 2001), mtDNA markers offer diagnostic characters that satisfy the requirement of lineage-based species definition (Sites \& Marshall 2004, Pons et al. 2006), showing to be an useful tool to assist traditional taxonomy in separating species where there is little discriminatory morphological variation (Hillis \& Wiens 2000, Ferguson 2002, Blaxter \& Floyd 2003). Thus several studies have used these markers, particularly control region sequence data, to gain insight into molecular evolution of Sebastes speciation (Rocha-Olivares et al. 1999a, Kai et al. 2002, Cope 2004, Gharrett et al. 2005, Hyde \& Vetter 2007).

The present study analyzes mitochondrial control region sequences under traditional phylogenetic methods (maximum likelihood and Bayesian analyses) adopting the concept of species as independent evolutionary lineages (De Queiroz 1998) and apply the Wiens \& Penkrot protocol (Wiens \& Penkrot 2002, Sites \& Marshall 2003), to assess boundaries between Pacific and Atlantic S. oculatus.

\section{Material And Methods}

\section{Fish SAMPLING}

We collected mitochondrial D-loop partial sequences for 47 specimens of Sebastes belonging to six localities from the southeastern Pacific coast, one locality from Peru (Huacho) and five localities from Chile (Iquique, Antofagasta, Coquimbo, Aysen channels, and Punta Arenas); one locality from the southwestern Atlantic

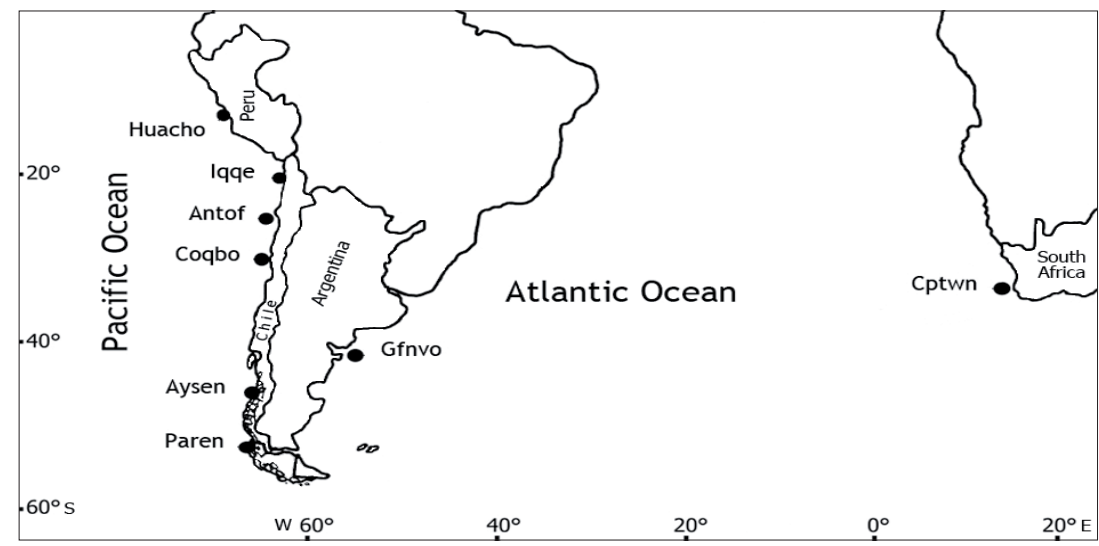

Figure 1. Map of the study area indicating the localities (solid circles). Sample codes as indicated in Table 1 / Mapa del área de estudio indicando las localidades (círculos sólidos). Los códigos de las muestras se indican en la Tabla 1 
Table 1. Locality, haplotype code, number of haplotypes, and genetic diversity parameters for each analyzed locality / Localidad, código del haplotipo, número de haplotipos y parámetros genéticos para cada localidad analizada

\begin{tabular}{|c|c|c|c|c|c|c|c|}
\hline Locality & Code & Haplotypes/ $N$ & $H \mathrm{~d}( \pm \mathrm{SD})$ & $\pi$ & $S$ & $\begin{array}{c}\text { Mean pairwise } \\
\text { divergence }( \pm \mathrm{SD})\end{array}$ & $\begin{array}{l}\text { Tajima's } \\
\text { D statistic }\end{array}$ \\
\hline Huacho, Peru (11 $\left.{ }^{\circ} 00^{\prime} S\right)$ & Huacho & $5 / 6$ & $0.93 \pm 0.12$ & 0.024 & 29 & $0.0249 \pm 0.005$ & -0.227 \\
\hline Iquique, Chile (20¹3’S) & Iqque & $5 / 5$ & $1.00 \pm 0.12$ & 0.013 & 13 & $0.0134 \pm 0.004$ & 0.195 \\
\hline Antofagasta, Chile $\left(23^{\circ} 38^{\prime} \mathrm{S}\right)$ & Antof & $4 / 5$ & $0.90 \pm 0.16$ & 0.019 & 17 & $0.0198 \pm 0.006$ & 1.657 \\
\hline Coquimbo, Chile (2958’s) & Coqbo & $9 / 9$ & $1.00 \pm 0.05$ & 0.012 & 17 & $0.0117 \pm 0.003$ & -0.457 \\
\hline Aysén, Chile (453''s) & Aysen & $5 / 5$ & $1.00 \pm 0.12$ & 0.012 & 14 & $0.0128 \pm 0.004$ & -0.609 \\
\hline 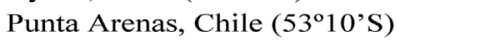 & Paren & $1 / 1$ & - & - & - & - & - \\
\hline 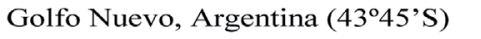 & Gfnvo & $7 / 7$ & $1.00 \pm 0.08$ & 0.064 & 61 & $0.0680 \pm 0.010$ & 1.360 \\
\hline Cape Town, South Africa ( $33^{\circ} 51^{\prime}$ 'S) & Cptwn & $6 / 9$ & $0.92 \pm 0.09$ & 0.018 & 18 & $0.0186 \pm 0.005$ & 0.282 \\
\hline Total & & $42 / 47$ & $0.994 \pm 0.06$ & 0.036 & 88 & $0.0394 \pm 0.007$ & -1.200 \\
\hline
\end{tabular}

(Golfo Nuevo, Argentina); and one from the South African (Cape Town) coast (Table 1, Fig. 1). Fishes were captured with hand lines from artisanal boats or by divers and were morphologically identified. We included D-loop partial sequence data from GenBank for S. capensis (AF031503), S. oculatus (AF031502), S. constellatus (AF031505), S. notius (AF031510), S. lentiginosus (AF031509), $S$. umbrosus (AF031516), S. exsul (AF031514), S. spinorbis (AF031515), S. chlorostictus (AF031504), $S$. eos (AF031506), S. rosenblatti (AF031511), S. helvomaculatus (AF031508), S. simulator (AF031513), S. ensifer (AF031507), S. rosaceus (AF031512), S. serranoides (AF031498), S. inermis (ab071260), S. maliger (AF031500), S. schlegelii (NC005450), S. paucispinis (AF031499), and S. ruberrimus (AF031501) (RochaOlivares et al. 1999a, Kai et al. 2002, Kim \& Lee 2004). Additionally, two specimens of Helicolenus lengerichi (a member of the subfamily Sebastinae where Sebastes is also included) were also obtained from Valdivia (Chile) to be used as outgroup.

\section{MoleCUlaR PROTOCOLS AND SEQUENCE ALIGNMENT}

Whole genomic DNA was extracted from tissue samples (muscle preserved in 98\% ethanol) using standard protocols of chemical digestion ( $0.1 \mathrm{M}$ Tris- $\mathrm{HCl} \mathrm{pH} \mathrm{8.0,} \mathrm{0.2M} \mathrm{EDTA,}$ $1 \% \mathrm{SDS}, 100 \mu \mathrm{g} \mathrm{mL}^{-1}$ proteinase $\mathrm{K}$ ) followed by phenol/ chloroform extraction (Sambrook et al. 1989). Air-dried DNA pellets were eluted in TE $\mathrm{pH}$ 8.0. mtDNA PCR amplifications were performed using 50 - $100 \mathrm{ng}$ of genomic DNA and 0.5 units of DNA polymerase (Invitrogen) per $50 \mu \mathrm{L}$ of reaction volume. Polymerase-chain-reaction (PCR) amplification and sequencing of the D-loop region was performed using the primers L15926 (Kocher et al. 1989) and H16498 (Meyer et al. 1990). The PCR cycling procedure was as follows: an initial denaturation at $94^{\circ} \mathrm{C}$ for $3 \mathrm{~min}$ followed by 35 cycles of $92^{\circ} \mathrm{C}$ for $50 \mathrm{sec}, 50^{\circ} \mathrm{C}$ for
$1 \mathrm{~min}$, and $72^{\circ} \mathrm{C}$ for $1 \mathrm{~min}$, followed by chain extension at $72^{\circ} \mathrm{C}$ for $7 \mathrm{~min}$. The size of the PCR products was checked against a 100 -bp DNA ladder on $1.5 \%$ agarose gels stained with $0.5 \mu \mathrm{g} \mathrm{mL}^{-1}$ ethidium bromide. Amplified fragments were purified using Qiaquick Purification kits (QIAGEN) following the manufacturer's instructions. Sequences were generated in both directions on an ABI 377 automatic sequencer according to manufacturer protocols. Sequences were edited with Bioedit 7.0 and then aligned using MAFFT v5.7 (Katoh et al. 2005) under the iterative method of global pairwise alignment (G-INS-i). Default settings were chosen for all the parameters involved. Sequences were submitted to GenBank under Accession Numbers GU136675-GU136720.

\section{NuCleotide DIVERSITY OF MT DNA SEQUeNCES}

Haplotype $(H \mathrm{~d})$ and nucleotide diversity ( $\pi$, Nei 1987), number of segregating sites $(S)$ for $S$. oculatus and $S$. capensis, and Tajima's $D$ (Tajima 1989) were estimated using DnaSP 5.0 (Librado \& Rozas 2009). Additionally, to evaluate whether sufficient samples for each locality were collected to characterize genetic diversity $(S)$, was plotted against number of sequences for each population.

\section{Phylogenetic analyses}

Maximum likelihood (ML) trees (Felsenstein 1981) were estimated using Garli v0.94 (Zwickl 2006) under the $\mathrm{HKY}+\Gamma$ model (Hasegawa et al. 1985), as suggested by Modeltest v3.7 under the Akaike Information Criterion (Posada \& Crandall 1998, Posada \& Buckley 2004). Likelihood topology tests were conducted using our molecular data and the Shimodaira \& Hasegawa (1999) test as implemented in Paup* v4b10 (Swofford 2002). Confidence in the resulting relationships was assessed using the nonparametric bootstrap procedure (Felsenstein 
1985 ) with 100 bootstrap replicates. Bayesian phylogeny estimation was performed using MrBayes v3.0 (Ronquist \& Huelsenbeck 2003). Each Markov chain was started from a random tree and run for $1.0 \times 10^{7}$ cycles with every 1,000 th cycle sampled from the chain. Model parameters were treated as unknown variables with uniform priors and were estimated as part of the analysis. We ran four chains simultaneously and each analysis was repeated three times. Stationarity was checked using Tracer v1.3 (Rambaut \& Drummond 2003). After initial inspection, the first 200 trees from each chain were discarded (burn-in phase).

We used Wiens \& Penkrot (2002) protocol to test species boundaries between Pacific and Atlantic oculatus lineages. This method is based on a sampling design that includes: (a) focal species (the species of interest in the study, S. oculatus) and nonfocal species (closely related reference species, $S$. capensis) to apply the exclusivity test (i.e., all members of a group share a more recent common ancestor with every other member of that group than any of them does with any non-member) for the focal species, and (b) at least two individuals per locality to make the between-population gene flow inferences. It requires a phylogeny of haplotypes of known locality and taxonomic designation. A topology that fails to recover haplotypes from a given locality as a clade is taken as evidence for potential gene flow between populations (i.e., focal species $=$ single species). The method is implemented using dichotomous flow charts that lead to several alternatives for making species-level decisions.

\section{ReSUltS}

\section{NUCLEOTIDE SEQUENCE ANALYSES}

Multiple sequence alignments of the amplified gene region consisted in part of the threonine transfer RNA (tRNAThr) gene, the proline tRNA (tRNAPro) gene and part of the control region. Exclusion of sites with missing data at both ends of the alignment resulted in 541 aligned positions. A total of 42 unique mtDNA haplotypes (Table 1) were found among the 47 specimens examined. Only one sequence from individuals with identical haplotypes was included in the phylogenetic analyses. Within S. capensis and S. oculatus, 88 sites were polymorphic. Tandem repeats or heteroplasmy were not detected, however a deletion of 75 nucleotides near to the 5' end of the D-loop region was observed in a specimen of the South African population. Results of the estimations of haplotype and nucleotide diversity and segregating sites, as well as results of Tajima tests, are summarized in Table 1. Sequence divergence was similar to other intraspecific comparisons (Cope 2004) for the same mtDNA region, except for the population of Golfo Nuevo $(6.8 \%, \mathrm{SD}=1.0 \%$, Table 1$)$. The segregating sites plotted against number of sequences for each population (Fig. 2) showed a moderated leveling indicating that possibly the localities were under sampled, situation that is more evident for the Golfo Nuevo locality.

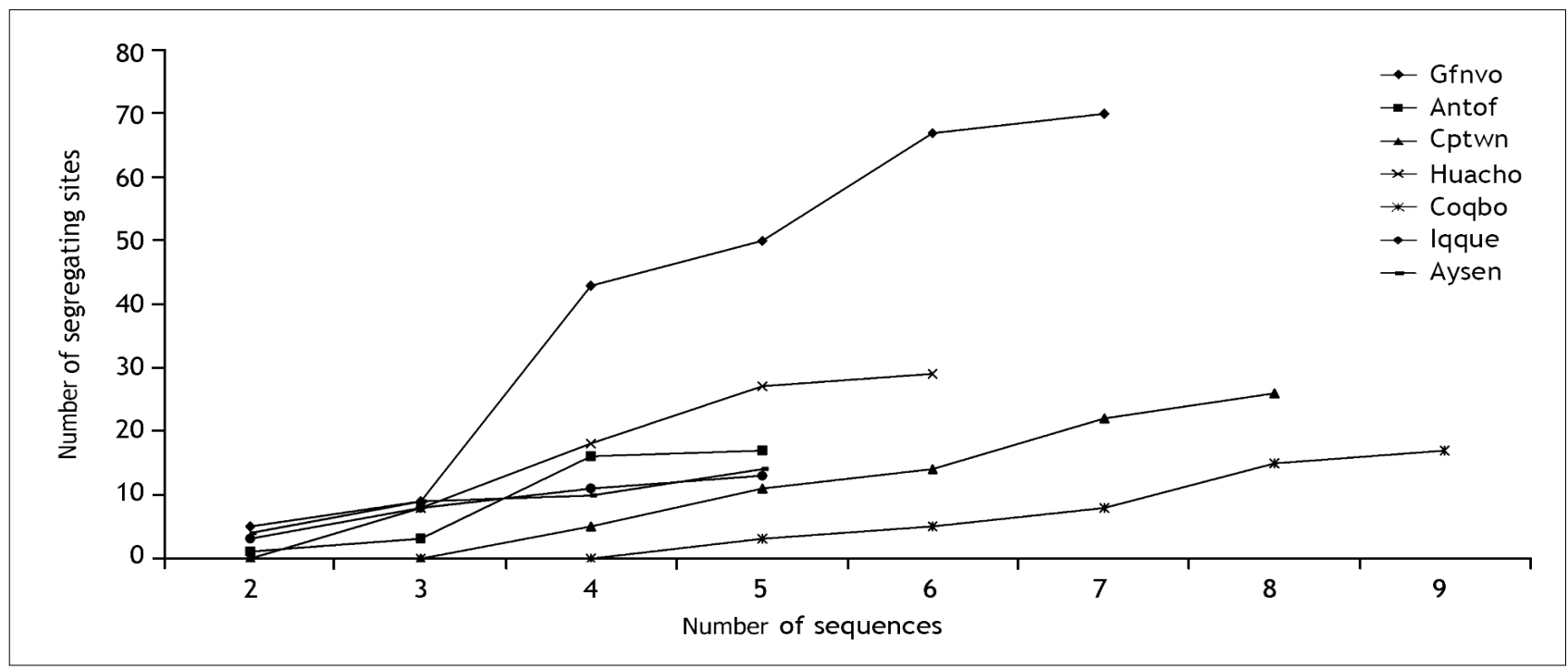

Figure 2. Cumulative segregating sites curves for six localities of S. oculatus and one locality of S. capensis. Punta Arenas locality was not included because only one sample was available. Sample codes as indicated in Table 1 / Curvas acumulativas de sitios segregantes de seis localidades de S. oculatus y una localidad de S. capensis. La localidad de Punta Arenas no fue incluida, dado que solo una muestra fue disponible. Los códigos de las muestras se indican en la Tabla 1 


\section{AND BAYESIAN PHYLOGENETIC ANALYSES}

The best-fit model of evolution for the phylogenetic analyses as indicated by Modeltest was the $\mathrm{HKY}+\Gamma$ model (Hasegawa et al. 1985): base frequencies $=0.3818$, $0.1720,0.1460,0.3002$; TRatio $=2.7544$, gamma shape $=0.3840$. One optimal ML topology was found $(\operatorname{lnL}=$ -3814.87). All phylogenetic trees constructed by both methods showed similar topologies. The inconsistence between both methodological approaches was in clades supported by low bootstraps and posterior probabilities. South African and South American populations formed separated lineages supported by bootstrap proportions $\geq 60 \%$ and Bayesian posterior probabilities $\geq 0.9$ (Fig. 3). Alternative paraphyletic hypotheses clustering South African and South American populations were rejected by the SH topological test $(P<0.05)$. Within the $S$. oculatus clade there was no complete separation of haplotypes into Pacific and Atlantic basins, with most terminals showing short branch lengths and low clade supports. Alternative monophyletic hypotheses separating Pacific and Atlantic populations were not rejected by the Shimodaira-Hasegawa test $(P>0.05)$. Additionally, the Wiens \& Penkrot's protocol indicates that $S$. oculatus and $S$. capensis are two different phylogenetic species. On the contrary, according to the same procedure Atlantic and Pacific $S$. oculatus lineages do not qualify as different Sebastes species.

\section{Discussion}

Sebastes sibling species have been often the center of taxonomic and nomenclature revisions (Seeb 1998, Kendall 2000) and molecular evolutionary studies have revealed recent speciation processes (Johns \& Avise 1998, Kai et al. 2002, Hyde \& Vetter 2007). In the southern hemisphere, S. capensis was the only recognized species, distributed from the Pacific coast of Peru and Chile to the Falkland Islands, and to the southwestern coast of South Africa (Chen 1971, Kong 1985). However, Eschmeyer \& Hureau (1971) considered that the Sebastes populations inhabiting the West coast of South America was S. oculatus, and only those populations from the southcentral Atlantic islands and South Africa were $S$. capensis. Rocha-Olivares et al. (1999b) using DNA sequences from hypervariable control region found that the southern hemisphere Sebastes is represented by $S$. capensis and two lineages of $S$. oculatus inhabiting the coasts of South America: one from the Pacific coasts and the other from the Atlantic coast. In their study, Rocha-Olivares et al. (1999b) used specimens from four sampling sites containing one locality from the southeastern Pacific coast (Valparaíso) and one from the southwestern Atlantic (Falkland Islands). Our analyses including more southeastern Pacific samples are partially concordant with those of Rocha-Olivares et al. (1999b) and previous hypotheses from Eschmeyer \& Hureau (1971) in the sense that specimens from South Africa and South America form two different phylogenetic species. Moreover, the SH test significantly rejected alternative topologies where these two lineages were presented as paraphyletic. However, neither Atlantic nor Pacific S. oculatus samples constituted reciprocal monophyletic assemblages in our tree (Fig. 3). Same result was also found by Rocha-Olivares et al. (1999b), where some specimens from the Falkland Islands were included within the Pacific $S$. oculatus and vice versa. The Shimodaira-Hasegawa test did not rejected alternative topologies separating Atlantic and Pacific specimens; hence the existence of two $S$. oculatus lineages in South American waters cannot be ruled out completely based on this topological test. The inadequate resolution of these internal nodes was likely due to the combination of small sample size and a single gene for phylogenetic information, fact that often creates long branches and polytomies (Hyde \& Vetter 2007).

According to Wiens \& Penkrot (2002), failure of haplotypes from the same locality to cluster together is potential evidence for gene flow between localities (i.e., focal species $=$ single species). Marine organisms usually exhibit high levels of gene flow (i.e., lack of population structuring) due to extensive larvae dispersal associated with planktonic life stages, the potential high vagility among adults, and high fecundity (Seeb 1998). Sebastes species have pelagic stages, but most species in this genus, including $S$. oculatus, show adult morphology concordant with sedentary habits (Alvarado 1985, Rocha-Olivares et al. 1999a, Gharrett et al. 2005). Females of this species retain the eggs until maturation. Pelagic larvae, that have been reported in coastal waters all along the Chilean coast are among the most abundant taxa in ichthyoplankton at the southern tip of South America (Bernal \& Balbontín 1999, Rodríguez-Graña \& Castro 2003, Landaeta \& Castro 2006), where fjords and channels dominate the coastline. Smaller larvae are principally above the halocline in the first $50 \mathrm{~m}$ of the water column throughout the channels and fjords, in contrast to the post-flexion larval stage that is more abundant seaward (Landaeta \& Castro 2006). This life history could suggest widespread larval dispersal and gene flow such as has been reported in other rockfish species (Buonaccorsi et al. 2002, Gilbert-Horvath et al. 2006). In addition, the inter-connectivity and larval dispersal of $S$. oculatus along the South American coast could be favored by both the Humboldt current and West Wind Drift current. 


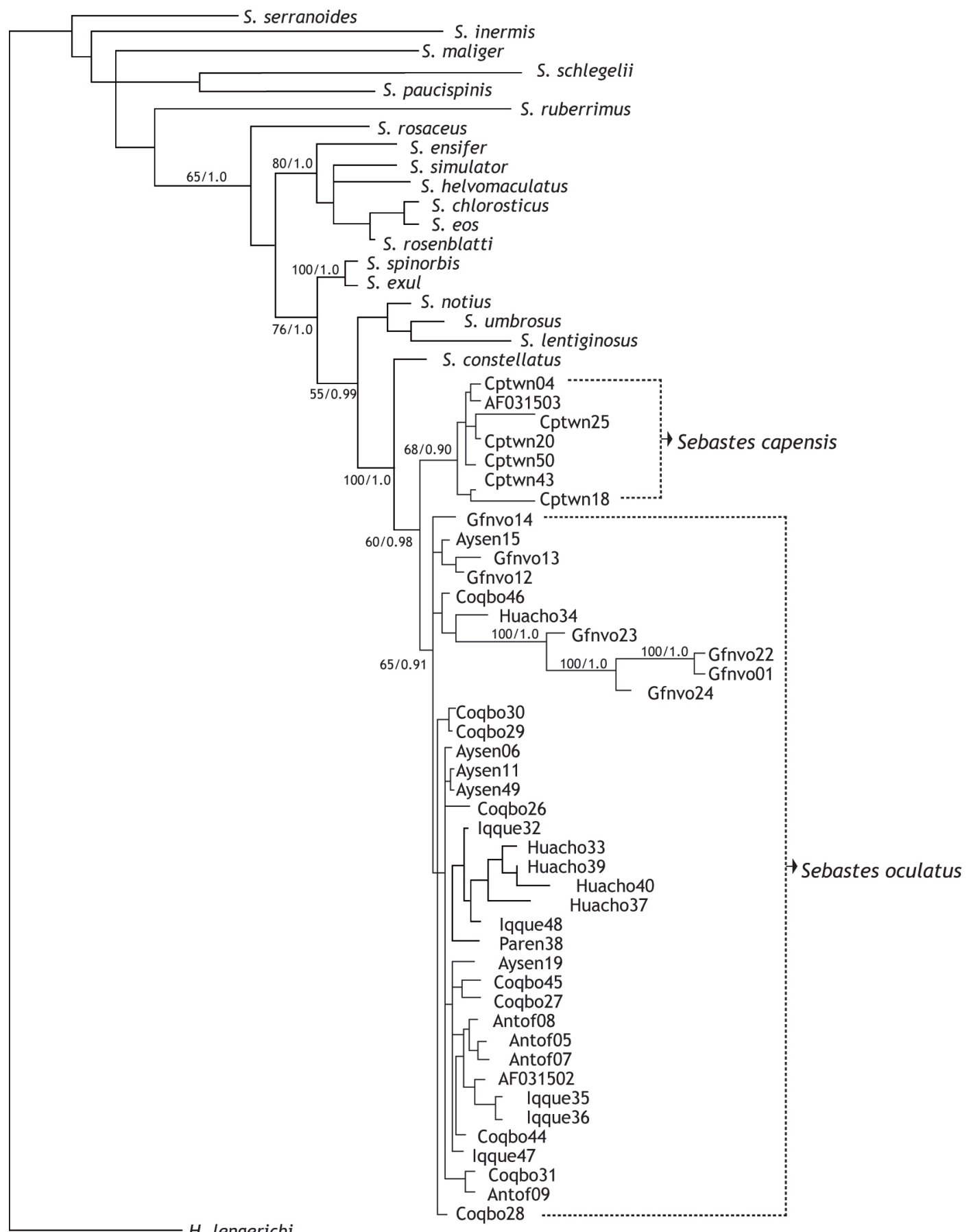

0.04 substitutions/site

Figure 3. Maximum likelihood phylogenetic tree of $S$. capensis and S. oculatus mtDNA control region haplotypes under the HKY $+\Gamma$ model. Bayesian analysis generated similar topologies. Clade supports (bootstrap proportions/Bayesian posterior probability) if $>50 \%$ are indicated for each node / Árbol filogenético de máxima verosimilitud de los haplotipos mitocondriales de $S$. capensis y $\mathrm{S}$. oculatus bajo el modelo HKY $+\Gamma$. El análisis Bayesiano generó similar topología. El soporte de los clados (proporción de bootstrap/ probabilidad a posteriori Bayesiana) se indican sobre el $50 \%$ en cada nodo 
Finally, if Atlantic and Pacific S. oculatus lineages are accepted as valid species alternative interpretations of our phylogenetic results would include: (1) overlapping distributional ranges of both taxa, (2) introgressive hybridization among the lineages or (3) incomplete lineagesorting of ancestral polymorphisms due to recent processes of speciation. The first and second alternatives can be tested upon a reliable identification and description of both sibling species and the posterior establishment of their distributional range. A molecular phylogeny using nuclear genes and fastevolving markers, such as microsatellites, as have been used in other studies (Roques et al. 1999, An et al. 2009) could also give clues about the potential of interbreeding between these The nature of microsatellite DNA loci has made them particularly amenable for genetic analyses of natural marine populations, and the applications of these markers are increasing in evaluating genetic structure of rockfishes (Sekino et al. 2001, Gómez-Uchida \& Banks 2005, Sotka et al. 2005), and species identification problems (Pampoulie \& Daníelsdóttir 2008). No doubt, these analyses can be strongly recommended to address the genetic divergence and speciation of Southern rockfishes in more detail. Nevertheless, until new evidence is presented, we conclude that, based on our results, Sebastes oculatus constitutes a single species in both the Atlantic and Pacific waters and is phylogentically distinct from its sister species, S. capensis, from southern South Africa.

\section{Aknowledgments}

The authors give special thanks to two anonymous reviewers for their valuable comments and suggestions on this manuscript. This work was supported by Project MECESUP UCO-0214 and Grant CONICyT AT-4040091.

\section{LiterATURE CITED}

Alvarado P. 1985. Aspectos tróficos y de morfología adaptativa de la cabrilla, Sebastes capensis (Gmelin, 1788) M. S. Thesis, Facultad de Ciencias, Universidad Austral de Chile, Valdivia, 70 pp.

An HS, JY Park, MJ Kim, EY Lee \& KK Kim. 2009. Isolation and characterization of microsatellite markers for the heavily exploited rockfish Sebastes schlegeli, and cross-species amplification in four related Sebastes spp. Conservation Genetics 10: 1969-1972. < doi 10.1007/ s10592-009-9870-8>

Barsukov VV. 1988. Rockfishes of the Sebastes inermis complex of the subgenus Sebastodes (Sebastes, Scorpaenidae). Journal of Ichthyology 31: 1-23.

Bernal R \& F Balbontín. 1999. Ictioplancton de los fiordos entre el Golfo de Penas y Estrecho de Magallanes y factores ambientales asociados. Ciencia y Tecnología del Mar 22: 143-154.

Blaxter M \& R Floyd. 2003. Molecular taxonomics for biodiversity survey: already a reality. Trends in Ecology and Evolution 18: 268-269.

Bond E \& AK Stockman. 2008. An integrative method for delimiting cohesion species: finding the population-species interface in a group of Californian trapdoor spiders with extreme genetic divergence and geographic structuring. Systematic Biology 57: 628-646.

Buonaccorsi VP, CA Kimbrell, EA Lynn \& RD Vetter. 2002. Population structure of copper rockfish (Sebastes caurinus) reflects postglacial colonization and contemporary patterns of larval dispersal. Canadian Journal of Fisheries and Aquatic Sciences 59: 1374-1384.

Chen LC. 1971. Systematics, variation, distribution, and biology of rockfishes of the subgenus Sebastomus (Pisces, Scorpaenidae, Sebastes). Bulletin of the Scripps Institution of Oceanography 18: 1-115.

Cope JM. 2004. Population genetics and phylogeography of the blue rockfish (Sebastes mystinus) from Washington to California. Canadian Journal of Fisheries and Aquatic Sciences 61: 332-342.

De Queiroz K. 1998. The general lineage concept of species, species criteria, and the process of speciation: A conceptual unification and terminological recommendations. In: Howard DJ \& SH Berlocher (eds). Endless forms: Species and speciation, pp. 57-75. Oxford University Press, Oxford.

Eschmeyer WN \& JC Hureau. 1971. Sebastes mouchezi, a senior synonym of Helicolenus tristanensis, with comments on Sebastes capensis and zoo-geographical considerations. Copeia 1971: 576-579.

Felsenstein J. 1981. Evolutionary trees from gene frequencies and quantitative characters: finding maximum likelihood estimates. Evolution 35: 1229-1242.

Felsenstein J. 1985. Confidence limits on phylogenies: an approach using the bootstrap. Evolution 39: 783-791.

Ferguson JWH. 2002. On the use of genetic divergence for identifying species. Biological Journal of the Linnean Society 75: 509-516.

Gharrett AJ, AP Matamala, EL Peterson, AK Gray \& L Zhouzhou. 2005. Two genetically distinct forms of rougheye rockfish are different species. Transactions of the American Fisheries Society 134: 242-260.

Gilbert-Horvath EA, RJ Larson \& JC Garza. 2006. Temporal recruitment patterns and gene flow in kelp rockfish (Sebastes atrovirens). Molecular Ecology 15: 3801-3815.

Gingras ML, DA Ventresca, MD Donnellan \& JL Fisher. 1998. First observations of vermillion rockfish courtship are from a harvest refuge. California Fish and Game 84: 176-179. 
Gómez-Uchida D \& MA Banks. 2005. Microsatellite analyses of spatial genetic structure in darkblotched rockfish (Sebastes crameri): is pooling samples safe? Canadian Journal of Fisheries and Aquatic Sciences 62: 1874-1886.

Hasegawa M, K Kishino \& T Yano. 1985. Dating the humanape splitting by a molecular clock of mitochondrial DNA. Journal of Molecular Evolution 22: 160-174.

Hillis DM \& JJ Wiens. 2000. Molecules versus morphology in systematics. In: Wiens JJ (ed). Phylogenetic analysis of morphological data, pp. 1-118. Smithsonian Institution Press, Washington.

Hyde JR \& RD Vetter. 2007. The origin, evolution, and diversification of rockfishes of the genus Sebastes (Cuvier). Molecular Phylogenetics and Evolution 44: 790-811.

Johns GC \& JC Avise. 1998. Test for ancient species flocks based on molecular phylogenetic appraisals of Sebastes rockfishes and other marine fishes. Evolution 52: 1135-1146.

Kai Y, K Nakayama \& T Nakabo. 2002. Genetic differences among three colour morphotypes of the black rockfish, Sebastes inermis, inferred from mtDNA and AFLP analyses. Molecular Ecology 11: 2591-2598.

Katoh K, K Kuma, H Toh \& T Miyata. 2005. MAFFT version 5: improvement in accuracy of multiple sequence alignment. Nucleic Acids Research 33: 511-518.

Kendall A. 2000. An historical review of Sebastes taxonomy and systematics. Marine Fisheries Review 62: 1-23.

Kim IC \& JS Lee. 2004. The complete mitochondrial genome of the rockfish Sebastes schlegeli (Scorpaeniformes, Scorpaenidae). Molecules and Cells 17: 322-328.

Kocher TD, WK Thomas, A Meyer, SV Edwards, S Paabo, EX Villablanca \& AC Wilson. 1989. Dynamics of mitochondrial DNA evolution in animals: amplification and sequencing with conserved primers. Proceedings of the National Academy of Sciences of the United States of America 86: 6196-6200.

Kong I. 1985. Revisión de las especies chilenas de Sebastes (Osteichthyes, Scorpaeniformes, Scorpaenidae). Estudios Oceanológicos 4: 21-75.

Landaeta MF \& LR Castro. 2006. Larval distribution and growth of the rockfish, Sebastes capensis (Sebastidae, Pisces), in the fjords of southern Chile. Journal of Marine Science 63: 714-724.

Librado P \& J Rozas. 2009. DnaSP v5: A software for comprehensive analysis of DNA polymorphism data. Bioinformatics 25: 1451-1452.

Meyer A, TD Kocher, P Basasibwaki \& AC Wilson. 1990. Monophyletic origin of Lake Victoria cichlid fishes suggested by mitochondrial DNA sequences. Nature 347 : 550-553.

Narum SR, VP Buonaccorsi, CA Kimbrell \& RD Vetter. 2004. Genetic divergence between gopher rockfish (Sebastes carnatus) and black and yellow rockfish (Sebastes chrysomelas). Copeia 2004: 926-931.
Nei M. 1987. Molecular evolutionary genetics, 512 pp. Columbia University Press, New York.

Nelson JS. 1994. Fishes of the world, 416 pp. John Wiley \& Sons, New York.

Orr JW \& JE Blackburn. 2004. The dusky rockfishes (Teleostei: Scorpaeniformes) of the North Pacific Ocean: resurrection of Sebastes variabilis (Pallas, 1814) and a redescription of Sebastes ciliatus (Tilesius, 1813). Fishery Bulletin 102: 328-348.

Palumbi SR, F Cipriano \& MP Hare. 2001. Predicting nuclear gene coalescence from mitochondrial data: The three-times rule. Evolution 55: 859-868.

Pampoulie C \& AK Daníelsdóttir. 2008. Resolving species identification problems in the genus Sebastes using nuclear genetic markers. Fisheries Research 93: 54-63.

Pons JT, G Barraclough, J Gomez-Zurita, A Cardoso, DP Duran, S Hazell, S Kamoun, WD Sumlin \& AP Vogler. 2006. Sequence-based species delimitation for the DNA taxonomy of undescribed insects. Systematic Biology 55: 595-609.

Posada D \& TR Buckley. 2004. Model selection and model averaging in phylogenetics: advantages of the AIC and Bayesian approaches over likelihood ratio tests. Systematic Biology 53: 793-808.

Posada D \& KA Crandall. 1998. MODELTEST: testing models of DNA substitution. Bioinformatics 14: 817-818.

Rambaut A \& AJ Drummond. 2003. Tracer: MCMC trace analysis tool. University of Oxford, Oxford [on-line] $<$ http://tree.bio.ed.ac.uk $>$.

Rocha-Olivares A, RH Rosenblatt \& RD Vetter. 1999a. Molecular evolution, systematics, and zoogeography of the rockfish subgenus Sebastomus (Sebastes, Scorpaenidae) based on mitochondrial cytochrome $b$ and control region sequences. Molecular Phylogenetics and Evolution 11: 441-458

Rocha-Olivares A, RH Rosenblatt \& RD Vetter. 1999b. Cryptic species of rockfishes (Sebastes: Scorpaenidae) in the Southern Hemisphere inferred from mitochondrial lineage. Journal of Heredity 90: 404-411.

Rocha-Olivares A, CA Krimbell, BJ Eitner \& RD Vetter. 1999c. Evolution of a mitochondrial cytochrome $b$ gene sequence in the species-rich genus Sebastes (Teleostei: Scorpaenidae) and its utility in the testing the monophyly of the subgenus Sebastomus. Molecular Phylogenetics and Evolution 11: 426-440.

Rodríguez-Graña L \& LR Castro. 2003. Ichthyoplankton distribution off the Peninsula de Mejillones, Chile $\left(23^{\circ} \mathrm{S}\right.$, $71^{\circ} \mathrm{W}$ ), under variable hydrographic conditions during the austral summer and winter of the 1997 El Niño. Hydrobiologia 501: 59-73.

Ronquist F \& JP Huelsenbeck. 2003. MrBayes 3: Bayesian phylogenetic inference under mixed models. Bioinformatics 19: $1572-1574$. 
Roques S, P Duchesne \& L Bernatchez. 1999. Potential of microsatellites for individual assignment: the North Atlantic redfish (genus Sebastes) species complex as a case study. Molecular Ecology 10: 1703-1717.

Ross HA, S Murugan \& WLS Li. 2008. Testing the reliability of genetic methods of species identification via simulation. Systematic Biology 57: 216-230.

Sambrook J, EF Fritsch \& T Maniatis. 1989. Molecular cloning: a laboratory manual, 545 pp. Cold Spring Harbour Laboratory, New York.

Seeb LW. 1998. Gene flow and introgression within and among three species of rockfishes Sebastes auriculatus, $S$. caurinus, and S. maliger. Journal of Heredity 89: 393-403.

Sekino S, N Takagi, M Hara \& H Takahashi. 2001. Analysis of microsatellite DNA polymorphisms in rockfish Sebastes thompsoni and application to population genetics studies. Marine Biotechnology 3: 45-52.

Shimodaira H \& M Hasegawa. 1999. Multiple comparisons of log-likelihoods with applications to phylogenetic inference. Molecular Biology and Evolution 16: 1114-1116.

Sites JW \& JC Marshall. 2003. Delimiting species: a renaissance issue in systematic biology. Trends in Ecology and Evolution 18: 462-470.

Sites JW \& JC Marshall. 2004. Empirical criteria for delimiting species. Annual Review of Ecology Evolution and Systematics 35: 199-227.
Sotka EE, JA Hempelmann \& CH Biermann. 2005. Genetic evidence of postglacial population expansion in Puget Sound rockfish (Sebastes emphaeus). Marine Biotechnology 7: 223-230.

Stransky C \& SE MacLellan. 2005. Species separation and zoogeography of redfish and rockfish (genus Sebastes) by otolith shape analysis. Canadian Journal of Fisheries and Aquatic Sciences 62: 2265-2276.

Swofford D. 2002. PAUP*: Phylogenetic Analysis using Parsimony (and other methods), Version 4.0 b10. Sinauer. [CD-ROM].

Tajima F. 1989. Statistical method for testing the neutral mutation hypothesis by DNA polymorphism. Genetics 123: 585-595.

Wiens JJ. 2007. Species delimitation: New approaches for discovering diversity. Systematic Biology 56: 875-878.

Wiens JJ \& TL Penkrot. 2002. Delimiting species based on DNA and morphological variation and discordant species limits in spiny lizards (Sceloporus). Systematic Biology 51: 69-91.

Zwickl DJ. 2006. Genetic algorithm approaches for the phylogenetic analysis of large biological sequence datasets under the maximum-likelihood criterion. PhD Dissertation, University of Texas at Austin, Austin, 125 pp.

Recibido el 04 de mayo de 2009 y aceptado el 16 de marzo de 2010 